\title{
Analysis of VTOL UAV Propellant Technology
}

\author{
Daeil Jo, Yongjin Kwon* \\ Department of Industrial Engineering, College of Engineering, Ajou University, Suwon, South Korea \\ Email: ${ }^{\star} y k 73 @ a j o u . a c . k r$
}

How to cite this paper: Jo, D. and Kwon, Y.J. (2017) Analysis of VTOL UAV Propellant Technology. Journal of Computer and Communications, 5, 76-82. https://doi.org/10.4236/jcc.2017.57008

Received: April 4, 2017

Accepted: May 16, 2017

Published: May 19, 2017

Copyright $\odot 2017$ by authors and Scientific Research Publishing Inc. This work is licensed under the Creative Commons Attribution International License (CC BY 4.0).

http://creativecommons.org/licenses/by/4.0/

(c) (i) Open Access

\begin{abstract}
Recently, the surge in the interests in unmanned aerial vehicles has soared dramatically worldwide due to many potential benefits foreseen by this technology. The most widespread use of the commercial drones is a multi-copter form of unmanned aerial vehicle, because of its vertical takeoff and landing (VTOL) capability. However, due to the structural characteristics, it has a disadvantage that the flight time is quite short, which is typically ranging between 15 to 30 minutes. The fixed wing type of unmanned aerial vehicles has a longer flight time and duration, but it is not easy to secure a safe landing space, especially in the city areas. For this reason, demand for vertical fixed take-off and landing aircraft is rapidly increasing throughout the world. This study analyzes the trends and recent development of global VTOL technology and provides a direction into which the current state of the technology should be heading. By comparing the advantage and disadvantage of various VTOP propulsion types, we can clearly identify the most effective form of VTOL propulsion types. Such analysis will be highly beneficial to the drone researchers and scientists in terms of future development.
\end{abstract}

\section{Keywords}

VTOL, UAV, Tail Sitter, Tilt Wing, Fixed Wing, Tiltrotor, Vertical Takeoff and Landing

\section{Introduction}

One can clearly see the recent surge and wide applications of unmanned aerial vehicles in many areas, such as agriculture, forestry, surveillance, rescue operations, security, aerial photographing, and so on. The most widespread use of the commercial drones is a multi-copter type of unmanned aerial vehicle. For example, most aerial photography drones are this type. It is because this type of drones doesn't require a length runway and it can hover in the air while filming. This kind of convenience is necessary, especially in the congested areas like city centers. However, it has a disadvantage that the flight time is too short (typically 
ranging between 15 to 30 minutes). The fixed wing type drones can stay afloat for a much longer time, typically over 1 or 2 hours. However, it is not always easy to find a safe landing space, and it is not easy to manually control this type of drones [1] [2]. Due to these reasons, the most commercial drones are multi-copter types.

The third type of unmanned aerial vehicle is often referred to as a VTOL drone, which can vertically takeoff and land, while flies like a fixed-wing aircraft once airborne. It doesn't require a runway, and land like a helicopter. The VTOL drone can hover in the air, yet capable of flying a much longer time. Due to these advantages, the VTOL drone is taking a great interest among researchers and commercial applications. In order for VTOL drones to hover and make a transit flight like airplane, its propulsion system should be very different than those of multi-copter type drone or fixed-wing type drones. Our initial analysis shows that there are so many varieties already developed, while a thorough study of analyzing VTOL types is not present until this time. In this regard, our goal is to collect the different types of VTOL propulsion technologies and analyze the advantages and disadvantages of each type. Such study will provide valuable insights for the drone community.

\section{Analysis of VTOL Propulsion Systems}

The analysis classifies each type of VTOL into 3 categories. This include: 1) TYPE1, which has a wing and a TILT-ROTOR, 2) TYPE 2, with no wings and similar to helicopters, and 3) TYPE 3 with wings and no tilting mechanism functions. The details are defined in Table 1 [3]-[10].

Tables 2-5 show the specifications of VTOL drones in major countries. In fact, there are over 35 VTOL drones we have identified. Due to similarities, in this paper, we only show the representative types of VTOL drones. Those are illustrated in the tables below.

\section{Analysis Contents}

First, the percentage of VTOL types has been investigated, as shown in Figure 1. It shows that the Type 2 and Types 3 take the majority of the VTOL drones. VTOL with a tilt mechanism only takes about $18 \%$. The reason can be conjectured that Type 1 drone can be unstable during the transit flight (i.e., from hover to forward flight), and the tilting mechanism can add substantial weights as well as increase the complexity in the system. Due to these reasons, the Type 1 VTOL drones are comparatively limited. Type 2 and Type 3 VTOL drones are quite

Table 1. Classification of VTOL types.

\begin{tabular}{cccc}
\hline & TYPE1 & TYPE2 & TYPE3 \\
\hline Wing & $\mathrm{O}$ & $\mathrm{X}$ & $\mathrm{O}$ \\
Tilt Rotor & $\mathrm{O}$ & $\mathrm{X}$ & $\mathrm{X}$ \\
VTOL & $\mathrm{O}$ & $\mathrm{O}$ & $\mathrm{O}$ \\
\hline
\end{tabular}


Table 2. There presentative VTOL drones in Korea and USA.

\begin{tabular}{|c|c|c|}
\hline Contents & Picture & Picture \\
\hline \multicolumn{3}{|l|}{ TYPE1 } \\
\hline Name & TR-100 & Sky Prowler \\
\hline Manufacturer & KARI & Krossblade Aerospace \\
\hline Country & South Korea & USA \\
\hline Length & $5.0 \mathrm{~m}$ & $0.5 \mathrm{~m}$ \\
\hline Payload & $100 \mathrm{~kg}$ & $0.5 \mathrm{~kg}$ \\
\hline Flying time & $5 \mathrm{hrs}$ & $1 \mathrm{hrs}$ \\
\hline propellant & Gasoline & Motor \\
\hline Max speed & $500 \mathrm{~km} / \mathrm{h}$ & $100 \mathrm{~km} / \mathrm{h}$ \\
\hline \multicolumn{3}{|l|}{ TYPE1 } \\
\hline Name & JOBY S2 & JOBY LOTUS \\
\hline Manufacturer & JOBY AVIATION & JOBY AVIATION \\
\hline Country & USA & USA \\
\hline Length & $\mathrm{N} / \mathrm{A}$ & N/A \\
\hline Payload & $176 \mathrm{~kg}$ & $27 \mathrm{~kg}$ \\
\hline Flying time & $15 \mathrm{hrs}$ & $1 \mathrm{hrs}$ \\
\hline propellant & Gasoline electric hybrid & Gasoline electric hybrid \\
\hline Max speed & $200 \mathrm{~km} / \mathrm{h}$ & $185 \mathrm{~km} / \mathrm{h}$ \\
\hline
\end{tabular}

Table 3. There presentative VTOL drones in Taiwan and Canada.

\begin{tabular}{|c|c|c|}
\hline Contents & Picture & Picture \\
\hline \multicolumn{3}{|l|}{ TYPE2 } \\
\hline Name & DTI RTN KSM 150 & APID 60 \\
\hline Manufacturer & $\mathrm{N} / \mathrm{A}$ & TOP Engineering \\
\hline Location & Taiwan & Taiwan \\
\hline Length & $2.1 \mathrm{~m}$ & $4.0 \mathrm{~m}$ \\
\hline Payload & $15 \mathrm{~kg}$ & $55 \mathrm{~kg}$ \\
\hline Flying time & $2.5 \mathrm{hrs}$ & $5 \mathrm{hrs}$ \\
\hline propellant & Gasoline & Gasoline \\
\hline Max speed & $100 \mathrm{~km} / \mathrm{h}$ & $110 \mathrm{~km} / \mathrm{h}$ \\
\hline \multicolumn{3}{|l|}{ TYPE2 } \\
\hline Name & Navig 8 Gas & Navig 8 Electric \\
\hline Manufacturer & 4FRONT ROBOTICS & 4FRONT ROBOTICS \\
\hline Country & Canada & Canada \\
\hline Length & $3.1 \mathrm{~m}$ & $1.64 \mathrm{~m}$ \\
\hline Width & $2.9 \mathrm{~m}$ & $1.0 \mathrm{~m}$ \\
\hline Payload & $31 \mathrm{~kg}$ & $4 \mathrm{~kg}$ \\
\hline Flying time & $2.5 \mathrm{hrs}$ & $1 \mathrm{hrs}$ \\
\hline propellant & Gasoline & MOTOR \\
\hline Max speed & $200 \mathrm{~km} / \mathrm{h}$ & $83 \mathrm{~km} / \mathrm{h}$ \\
\hline
\end{tabular}


Table 4. There presentative VTOL drones in Japan and USA.

\begin{tabular}{|c|c|c|}
\hline Contents & Picture & Picture \\
\hline \multicolumn{3}{|l|}{ TYPE3 } \\
\hline Name & SR-1 & ARCTURUS JUMP-20 \\
\hline Manufacturer & CQV & ARCTURUS \\
\hline Country & Japan & USA \\
\hline Length & $1.7 \mathrm{~m}$ & $2.9 \mathrm{~m}$ \\
\hline Payload & $0.7 \mathrm{~kg}$ & $27 \mathrm{~kg}$ \\
\hline Flying time & $0.5 \mathrm{hrs}$ & $9 \mathrm{hrs}$ \\
\hline propellant & MOTOR & Gasoline \\
\hline Max speed & $55 \mathrm{~km} / \mathrm{h}$ & $133 \mathrm{~km} / \mathrm{h}$ \\
\hline TYPE3 & $\sum_{n=1}$ & ank \\
\hline Name & V-Bat & Current MK1 \\
\hline Manufacturer & MARTIN UAV & Current MK1 (MK2) \\
\hline Country & USA & USA \\
\hline Length & $2.4 \mathrm{~m}$ & $2.0 \mathrm{~m}$ \\
\hline Payload & $2 \mathrm{~kg}$ & $18.5 \mathrm{~kg}$ \\
\hline Flying time & $8 \mathrm{hrs}$ & $15 \mathrm{hrs}$ \\
\hline propellant & Gasoline & Gasoline \\
\hline Max speed & $350 \mathrm{~km} / \mathrm{h}$ & $148 \mathrm{~km} / \mathrm{h}$ \\
\hline
\end{tabular}

similar in terms of numbers among the drone that we have investigated. Each type bears specific merits and also disadvantages, so each type takes about the same percentages. Second, we have analyzed each type according to the number of criteria investigated. The results are organized in Table 5 and Table 6. The table mainly shows the engine types (electric motors, gasoline powered, diesel, or hybrid engines), and flight durations (less than 2 hours of flying time, less than 4 hours, and over 4 hours).

By analyzing the content of the payload specification, the larger the size of the airframe, the more likely it was to see the airframe size increase. It appears to affect the flight time with drag on airframe, depending on whether or not the airframe is aerodynamically well balanced. Third, we have classified the VTOL drone in accordance with their size and payload. It appears that the size and payload will continue to increase in the future.

\section{Conclusion}

The analysis shows that the higher the payload, the bigger the size of the aircraft. 
Table 5. Analysis of VTOL propellant technology.

\begin{tabular}{|c|c|c|c|c|c|c|c|c|}
\hline \multirow{2}{*}{$\begin{array}{l}\text { VTOL } \\
\text { TYPE }\end{array}$} & \multirow{2}{*}{ Model } & \multicolumn{4}{|c|}{ Engine Type } & \multicolumn{3}{|c|}{ Flying Time } \\
\hline & & Motor & Gasoline & Diesel & Hybrid & $2 \mathrm{Hr} \downarrow$ & $4 \mathrm{Hr} \downarrow$ & $4 \mathrm{Hr} \uparrow$ \\
\hline \multirow{6}{*}{ TYPE 1} & FE-Panther & & & & $\mathrm{O}$ & - & - & - \\
\hline & KUS-TR (TR-60) & & $\mathrm{O}$ & & & & & $\mathrm{O}$ \\
\hline & TR-100 & & $\mathrm{O}$ & & & & & $\mathrm{O}$ \\
\hline & Sky Prowler & $\mathrm{O}$ & & & & $\mathrm{O}$ & & \\
\hline & JOBY S2 & & $\mathrm{O}$ & & & & & $\mathrm{O}$ \\
\hline & JOBY LOTUS & & & & $\mathrm{O}$ & - & - & - \\
\hline \multirow{12}{*}{ TYPE 2} & Air Mule & & & & $\mathrm{O}$ & - & - & - \\
\hline & Airbus DS Tanan 300 & & & $\mathrm{O}$ & & - & - & - \\
\hline & HEF32 & & $\mathrm{O}$ & & & & & $\mathrm{O}$ \\
\hline & VSR700 & & $\mathrm{O}$ & & & & & $\mathrm{O}$ \\
\hline & DTI RTN KSM 150 & & $\mathrm{O}$ & & & & $\mathrm{O}$ & \\
\hline & APID 60 & & $\mathrm{O}$ & & & & $\mathrm{O}$ & \\
\hline & Navig 8 Gas & & $\mathrm{O}$ & & & & $\mathrm{O}$ & \\
\hline & Navig 8 Electric & $\mathrm{O}$ & & & & $\mathrm{O}$ & & \\
\hline & DP-6XT WHISPER & $\mathrm{O}$ & & & & $\mathrm{O}$ & & \\
\hline & UAV IT180-120 & & $\mathrm{O}$ & & & $\mathrm{O}$ & & \\
\hline & DP-12 RHINO & & $\mathrm{O}$ & & & & $\mathrm{O}$ & \\
\hline & DP-14 HAWK & & $\mathrm{O}$ & & & & $\mathrm{O}$ & \\
\hline \multirow{12}{*}{ TYPE 3} & Aerosense & $\mathrm{O}$ & & & & $\mathrm{O}$ & & \\
\hline & Wingtra & - & - & - & - & - & - & - \\
\hline & VD 200 & - & - & - & - & & $\mathrm{O}$ & \\
\hline & X-Plane & & $\mathrm{O}$ & & & - & - & - \\
\hline & SR-1 & $\mathrm{O}$ & & & & $\mathrm{O}$ & & \\
\hline & ARCTURUS JUMP-20 & & $\mathrm{O}$ & & & & & $\mathrm{O}$ \\
\hline & V-Bat & & $\mathrm{O}$ & & & & & $\mathrm{O}$ \\
\hline & Current MK1 (MK2) & & $\mathrm{O}$ & & & & & $\mathrm{O}$ \\
\hline & FALCON-V & & $\mathrm{O}$ & & & & & $\mathrm{O}$ \\
\hline & PIGEON-V & $\mathrm{O}$ & & & & $\mathrm{O}$ & & \\
\hline & JOUAV CW-20 & & & & $\mathrm{O}$ & & & $\mathrm{O}$ \\
\hline & FOXY pro & $\mathrm{O}$ & & & & $\mathrm{O}$ & & \\
\hline
\end{tabular}

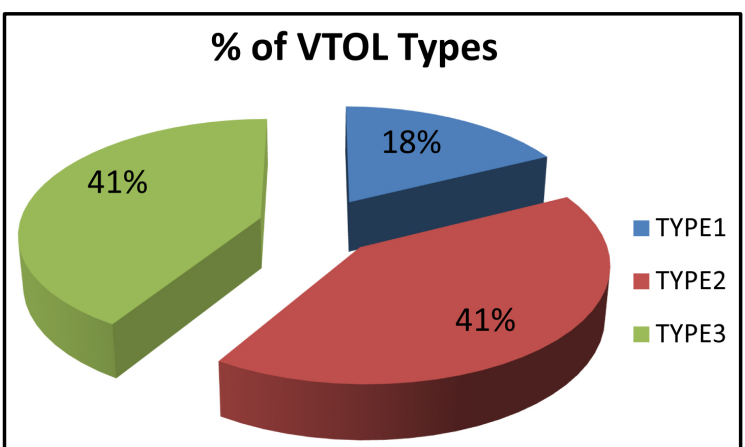

Figure 1. The percentage of VTOL types. 
Table 6. Analysis of payload and wing span of VTOL drones.

\begin{tabular}{|c|c|c|c|c|c|c|c|}
\hline \multirow{2}{*}{$\begin{array}{l}\text { VTOL } \\
\text { TYPE }\end{array}$} & \multirow{2}{*}{ Model } & \multicolumn{3}{|c|}{ Payload } & \multicolumn{3}{|c|}{ Wing Span } \\
\hline & & $10 \mathrm{Kg} \downarrow$ & $20 \mathrm{Kg} \downarrow$ & $20 \mathrm{Kg} \uparrow$ & $2 \mathrm{~m} \downarrow$ & $5 \mathrm{~m} \downarrow$ & $5 \mathrm{~m} \uparrow$ \\
\hline \multirow{6}{*}{ TYPE1 } & FE-Panther & $\mathrm{O}$ & & & & $\mathrm{O}$ & \\
\hline & KUS-TR (TR-60) & & & $\mathrm{O}$ & & $\mathrm{O}$ & \\
\hline & TR-100 & & & $\mathrm{O}$ & & & $\mathrm{O}$ \\
\hline & Sky Prowler & $\mathrm{O}$ & & & $\mathrm{O}$ & & \\
\hline & JOBY S2 & & & $\mathrm{O}$ & & & $\mathrm{O}$ \\
\hline & JOBY LOTUS & & & $\mathrm{O}$ & & & $\mathrm{O}$ \\
\hline \multirow{13}{*}{ TYPE2 } & Air Mule & & & $\mathrm{O}$ & & & $\mathrm{O}$ \\
\hline & Airbus DS Tanan 300 & & & $\mathrm{O}$ & & & $\mathrm{O}$ \\
\hline & HEF 32 & $\mathrm{O}$ & & & & $\mathrm{O}$ & \\
\hline & VSR 700 & & & $\mathrm{O}$ & & & $\mathrm{O}$ \\
\hline & DTI RTN KSM 150 & & $\mathrm{O}$ & & $\mathrm{O}$ & & \\
\hline & APID 60 & & & $\mathrm{O}$ & & $\mathrm{O}$ & \\
\hline & Navig 8 Gas & & & $\mathrm{O}$ & & $\mathrm{O}$ & \\
\hline & Navig8 Electric & $\mathrm{O}$ & & & $\mathrm{O}$ & & \\
\hline & DP-6XT WHISPER & & $\mathrm{O}$ & & $\mathrm{O}$ & & \\
\hline & DP-5X WASP & & & $\mathrm{O}$ & - & - & - \\
\hline & UAV IT180-120 & $\mathrm{O}$ & & & $\mathrm{O}$ & & \\
\hline & DP-12 RHINO & & & $\mathrm{O}$ & $\mathrm{O}$ & & \\
\hline & DP-14 HAWK & & & $\mathrm{O}$ & & $\mathrm{O}$ & \\
\hline \multirow{13}{*}{ TYPE3 } & Aerosense & $\mathrm{O}$ & & & $\mathrm{O}$ & & \\
\hline & Wingtra & $\mathrm{O}$ & & & - & - & - \\
\hline & VD 200 & & $\mathrm{O}$ & & & $\mathrm{O}$ & \\
\hline & X-Plane & & & $\mathrm{O}$ & & & $\mathrm{O}$ \\
\hline & SR-1 & $\mathrm{O}$ & & & $\mathrm{O}$ & & \\
\hline & ARCTURUS JUMP-20 & & & $\mathrm{O}$ & & & $\mathrm{O}$ \\
\hline & V-Bat & $\mathrm{O}$ & & & & $\mathrm{O}$ & \\
\hline & Current MK1 (MK2) & & $\mathrm{O}$ & & & $\mathrm{O}$ & \\
\hline & FALCON-V & $\mathrm{O}$ & & & & $\mathrm{O}$ & \\
\hline & PIGEON-V & $\mathrm{O}$ & & & $\mathrm{O}$ & & \\
\hline & JOUAV CW-20 & $\mathrm{O}$ & & & & $\mathrm{O}$ & \\
\hline & FOXY pro & $\mathrm{O}$ & & & & $\mathrm{O}$ & \\
\hline & JOUAV CW-10 & $\mathrm{O}$ & & & & $\mathrm{O}$ & \\
\hline
\end{tabular}

It is more likely that a bigger air frame affects the flight time. For drones that use electric motors, the battery capacity is directly related to the flight time. However, a bigger battery size inversely affects the payload capacity. According to the analysis of three types, it appears that the fixed wing type VTOL drones with no tilting mechanism are getting more and more popular. It is due to the facts that this type of VTOL drone can provide a stable transit flight while reducing the complexity associated with tilting mechanism. So the drones can be built at a lower cost and a lot lighter. It is judged that the surge in global demand for a 
wide range of VTOL drone is expected, and a growing competition is expected around the world.

\section{Acknowledgements}

This work was supported by the Ajou University research fund.

\section{References}

[1] Panther-FE Fixed Wing VTOL Drone Demonstrated in Flight. http://dx.doi.org/10.1080/028418501127346846

[2] Yu, S., Heo, J., Jeong, S. and Kwon, Y.J. (2016) Technical Analysis of VTOL UAV. Journal of Computer and Communications, 4, 92-97. https://doi.org/10.4236/jcc.2016.415008

[3] The 16-Rotor Convertible Aircraft for Long-Range, High-Speed, Electric VTOL Commuting. http://newatlas.com/joby-s2-tilt-rotor-vtol-multirotor-aircraft-concept/40662/

[4] Kang, Y.S. (2015) Tilt-Rotor UAV System to Monitor Illegal Fishing. KIRI.

[5] High Eye VTOL Manufacture. http://www.higheye.nl/hef-32/

[6] Airbus to Fly VSR700 VTOL UAV before End of the Year. http://www.janes.com/article/67281/airbus-to-fly-vsr700-vtol-uav-before-end-of-th e-year

[7] APID-55 VTOL Minature UAV. http://www.airforce-technology.com/projects/cybaero-apid55-uav/

[8] Watch Sony's First Aerosense Drone Take Flight. https://techcrunch.com/2015/08/24/watch-sonys-first-aerosense-drone-take-flight/

[9] JUMP 20 VTOL Unmanned Aerial Vehicle. http://www.naval-technology.com/projects/jump-20-vtol-unmanned-aerial-vehicle/

[10] Fisher Jr, R.D. (2016) China Reveals Data on VD200 Flying-Wing VTUAV. Washington DC, IHS Jane's Defence Weekly, 30 March.

Submit or recommend next manuscript to SCIRP and we will provide best service for you:

Accepting pre-submission inquiries through Email, Facebook, LinkedIn, Twitter, etc. A wide selection of journals (inclusive of 9 subjects, more than 200 journals)

Providing 24-hour high-quality service

User-friendly online submission system

Fair and swift peer-review system

Efficient typesetting and proofreading procedure

Display of the result of downloads and visits, as well as the number of cited articles Maximum dissemination of your research work

Submit your manuscript at: http://papersubmission.scirp.org/

Or contact jcc@scirp.org 